\title{
Botanical composition of bison diets on tallgrass prairie in Oklahoma
}

\author{
BRYAN R. COPPEDGE, DAVID M. LESLIE, JR., AND JAMES H. SHAW
}

Authors are former research assistant, Oklahoma Cooperative Fish and Wildlife Research Unit; unit leader, U.S. Geological Survey, Biological Resources Division, Oklahoma Cooperative Fish and Wildlife Research Unit; and professor, Department of Zoology, Oklahoma State University, Stillwater, Okla. 74078.

\begin{abstract}
Diets of bison (Bison bison L.) were examined using microhistological fecal analysis in a 2-yr study on a tallgrass prairie site in northcentral Oklahoma. Graminoids comprised at least $98 \%$ of the diet across all seasons. Bison showed strong feeding selectivity; grasses and sedges formed a significantly higher proportion of diets than was generally available in herbage on the landscape. Bison avoided forbs, which were $\leq 2 \%$ of the diet. Sedges were a large (17-44\%) diet component in winter and spring but decreased substaintially during summer and fall (11-16\%). These changes in sedge use corresponded to seasonal variation in sedge availability. Our results confirm that bison are primarily grazers in prairie habitats, potentially having a significant role in shaping structure and function of tallgrass prairie.
\end{abstract}

Key Words: Bison bison, grazing, bluestems, grasses, sedges, forbs.

The American bison (Bison bison L.) is the largest native herbivore in North America. Estimates of historic populations range from 30 to 60 million (Shaw 1995), but overhunting late in the 19th century virtually eliminated the species (Garretson 1938). Today, scattered populations of bison are confined to large fenced rangelands throughout the continent. Contemporary studies have been conducted on bison diets to understand the ecological role of bison grazing in the development and maintenance of central North American grasslands (Axelrod 1985). There are 3 major types of grasslands in central North America: shortgrass prairie, mixed-grass prairie, and tallgrass prairie (Axelrod 1985, Risser et al. 1981). Bison diet studies have been conducted only on shortgrass (Peden et al. 1974, Peden 1976, Kautz and Van Dyne 1978, Schwartz and Ellis 1981) and mixed-grass (Wydeven and Dahlgren 1985, Plumb and Dodd 1993) prairies. Knowledge of dietary habits of bison on tallgrass prairie is lacking because most tallgrass prairie has been eliminated by conversion to farms and croplands (Risser et al. 1981). With continued efforts and interest in restoring and preserving this grassland ecosystem (Joern and Keeler 1994), a study on the diets of bison on a tallgrass site was needed.

This study was funded by a grant from the Nature Conservancy and by the Oklahoma Cooperative Fish and Wildlife Research Unit (U.S.G.S. Biol. Res. Div., Okla. Dept. Wildl. Conserv., Wildl. Manage. Inst., and Okla. State Univer., cooperating). The authors wish to thank D.M. Engle and T.S. Carter for constructive commenus un earlier versions of this manuscript.

Manuscript accepted 23 Jul. 1997.
In 1989, the Nature Conservancy, a private conservation organization, established the Tallgrass Prairie Preserve in Oklahoma. As part of their efforts to restore a functioning tallgrass prairie ecosystem, 300 bison were released on the site in 1993 . This provided us the opportunity to conduct a baseline study on seasonal diet composition and feeding preferences of bison in a tallgrass pairie landscape.

\section{Study Area}

The study was conducted in 1994 and 1995 on the Nature Conservancy's Tallgrass Prairie Preserve (TPP), a 15,342-ha tallgrass prairie in the Osage Hills of northern Oklahoma $\left(36^{\circ} 50^{\prime} \mathrm{N}\right.$, $\left.96^{\circ} 25^{\prime} \mathrm{W}\right)$. Vegetation of the area was dominated by big bluestem (Andropogon gerardii Vitman), indiangrass (Sorghastrum nutans [L.] Nash), switchgrass (Panicum virgatum L.), and little bluestem (Schizachyrium scoparium [Michx.] Nash). Subdominant species included tall dropseed (Sporobolus asper (Michx.) Kunth) and sedges (Carex spp.). Common forbs were western ragweed (Ambrosia psilostachya DC.) and annual broomweed (Gutierrezia dracunculoides (DC.) Nutt.). Average monthly temperatures range from a low of $-50^{\circ} \mathrm{C}$ in January to a high of $34.4^{\circ} \mathrm{C}$ in July. Average total annual precipitation is 877 $\mathrm{mm}$; with 70\% occurring between April and September (Bourlier et al. 1979). Maintenance of tallgrass prairie is dependent on periodic burning (Collins and Wallace 1990), so preserve management included prescribed burning $20 \%$ of the area each year (Coppedge 1996).

Three hundred bison were reintroduced into a fenced 1,973-ha part of the preserve in October 1993. Following natural herd recruitment and the release of 43 additional animals, the area allocated to bison was expanded by 292-ha in August 1995 to maintain a stocking density of 6-7 ha $\mathrm{AU}^{-1}$ during our study. Herd management was limited to annual roundups for inoculations, weighing, and culling.

\section{Methods}

Field work was conducted during 4 seasonal periods each; winter (15 Jan.-15 Feb.), spring (15 Apr.-15 May), summer (15 Jul.-15 Aug.), and fall (15 Oct.-15 Nov.). Six composite fecal samples were collected during each period. Each sample consisted of $10 \mathrm{~g}$ of fresh fecal material collected from $4-6$ fecal pats 
deposited by herd members; therefore, diets of 24-36 randomly selected animals were represented in each sampling. Because of potential differnces in diets due to sexual segregation of adults (McHugh 1958, Main and Coblentz 1990), we analyzed fecal samples only from mixed groups of bison. These groups were composed of cows, yearlings, calves, and young ( $<5 \mathrm{yrs}$. of age) bulls which comprised $>90 \%$ of the population. The remainder of the population was comprised of mature bulls ( $>5 \mathrm{yrs}$. of age) that were usually segregated into bull-only groups except during the July mating season (McHugh 1958).

Diet composition was estimated with microhistological fecal analysis conducted by the Composition Analysis Laboratory, Ft. Collins, Colo., following the methods of Sparks and Malechek (1968). Twenty fields were examined on each of 3 slides representing each composite sample. Plant fragments were identified to the lowest possible taxon, which in most cases was to genus. Contribution of each item to bison diet composition was determined by converting frequency of occurrence to relative percent density (Hansen et al. 1976).

Composition of available current year's standing crop was estimated for each seasonal period with the dry-weight-rank method (Gillen and Smith 1986) conducted along ten, 100-m transects distributed in areas frequently grazed by bison and where fecal collections were made. Herbage components estimated were grasses and grasslike (Poaceae and Juncaceae), sedges (Cyperaceae), and forbs (all non-woody Dicotyledonae). Because woody browse was a very minor part of the vegetation, it's availability was not measured. Rankings of 1,2 , or 3 were assigned to $100,0.1 \mathrm{~m}^{2}$ quadrats placed randomly along transects. A ranking of 1 represented the most abundant forage item by weight within the quadrat. When a quadrat did not contain 3 items, all ranks were still assigned according to abundance. For example, a forage group comprising $85 \%$ or more of the standing crop received both rank 1 and 2, with rank 3 being assigned to the second most abundant item. Cumulative rankings were converted to herbage composition with a series of standard multipliers (Gillen and Smith 1986).

A diet selectivity index was calculated for each forage class as the ratio of each class percentage in the diet to its percentage availability in the herbage (Plumb and Dodd 1993). An index value of 1.0 indicated nonselective use of a forage class; values $>$ 1.0 or $<1.0$ indicated grazing selectivity for or against a particular class, respectively. Selectivity was tested by calculating a $95 \%$ confidence interval around each mean selectivity value following the formulae of Hobbs and Bowden (1982). Selectivity was significant when the interval did not contain the value 1.0 (Hobbs and Bowden 1982). Although Loehle and Rittenhouse (1982) criticized selectivity indices for their lack of predictive power in diet studies, Lechowicz (1982) concluded that such indices were appropriate when used as an assessment of general feeding patterns. Because our goal was to ascertain broad feeding preferences of bison and not to make predictions of future diets, we considered this index suitable for our purposes.

\section{Results and Discussion}

Grasses formed the majority (56-89\%) of bison diets in all seasons (Table 1). Many of the dominant tallgrasses in the study area were indistinguishable in fecal samples; therefore, these grasses were grouped into a 'bluestem' category that was usually the single largest dietary component. Other common grasses in the diet

Table 1. Relative percent composition ( $\bar{x} \pm$ se) of bison seasonal diets on tallgrass prairie in Oklahoma, 1994-1995, as determined from composite fecal samples.

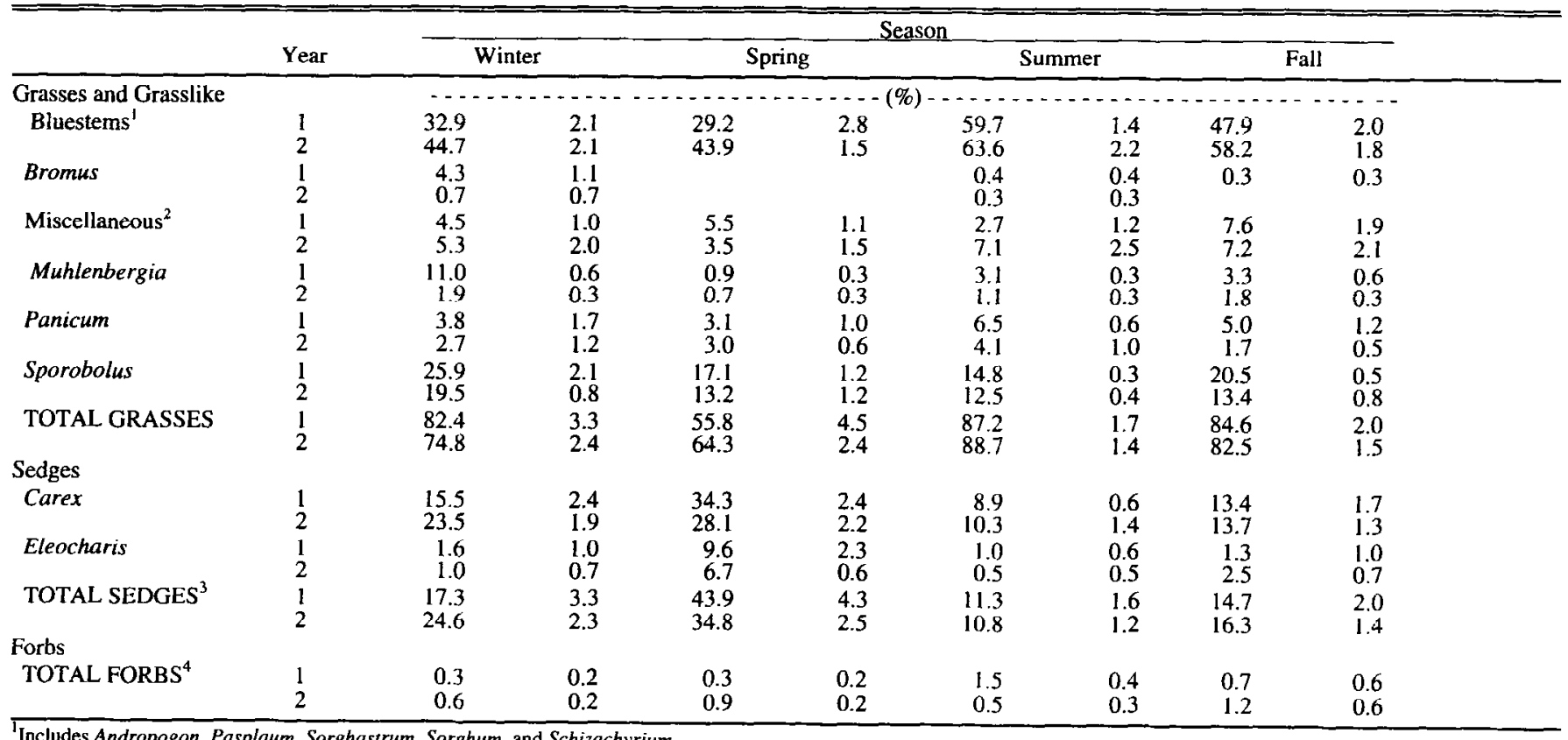

${ }^{1}$ Includes Andropogon, Pasplaum, Sorghastrum, Sorghum, and Schizachyrium.

${ }^{2}$ Items that did not exceed $3.0 \%$ in any diet; includes Agropyron, Agrostis, Aristida, Bouteloua, Cynodon, Elymus, Festuca, Juncus. Leptoloma. Poa. Phleum, Setaria, Tridens, Tripscacum, and unknown grasses.

${ }^{3}$ Includes unknown sedges. ${ }^{4}$ Includes a negligible browse component. No single item exceeded $1.0 \%$ in any diet; includes Artemisia, Croton, Desmodium, Juniperus, Medicago, Melilotus, Plantago, Quercus,
and unknown forbs. 
Table 2. Relative percent composition ( $\bar{x} \pm$ SE) of available standing crop by season on tallgrass prairie in Oklahoma, 1994-1995, as determined by the dry-weight-rank method (Gillen and Smith 1986).

\begin{tabular}{lccccccccc}
\hline & & \multicolumn{1}{c}{ Season } \\
\cline { 3 - 10 } Forage Class & Year & \multicolumn{2}{c}{ Winter } & \multicolumn{2}{c}{ Spring } & \multicolumn{1}{c}{ Summer } & \multicolumn{2}{c}{ Fall } \\
\hline \multirow{3}{*}{ Grasses } & 1 & 87.2 & 4.5 & 52.8 & 4.4 & 55.9 & 5.1 & 68.5 & 5.6 \\
& 2 & 77.0 & 6.0 & 38.5 & 3.9 & 46.1 & 3.7 & 58.5 & 4.8 \\
\multirow{4}{*}{ Sedges } & 1 & 6.0 & 1.1 & 17.8 & 1.3 & 5.6 & 0.1 & 5.1 & 0.4 \\
& 2 & 5.7 & 0.8 & 25.5 & 3.0 & 11.1 & 1.3 & 9.3 & 1.2 \\
\multirow{3}{*}{ Forbs } & 1 & 6.8 & 4.6 & 29.4 & 4.5 & 38.5 & 5.0 & 26.4 & 5.7 \\
& 2 & 17.3 & 5.9 & 36.0 & 2.2 & 42.8 & 3.5 & 32.2 & 5.2 \\
\hline
\end{tabular}

included Sporobolus, Muhlenbergia, and Panicum. Sedges, primarily Carex, comprised $17-44 \%$ of winter and spring diets but decreased substantially during summer and fall (11-16\%). Forbs never comprised $>2 \%$ of any diet.

Seasonal variation in composition of available forage was evident. Grasses were most abundant during winter $(77-87 \%$ of herbage) and fall (59-69\% of herbage), but decreased to $39-56 \%$ composition during spring and summer when forbs became more prevalent (Table 2). Sedges were most abundant during spring, comprising 18 to $26 \%$ of the herbage, but decreased to half these levels during winter, summer, and fall.

Seasonal trends in bison diet selectivity were evident. Grasses were consumed either in equal proportion to or slightly above their seasonal availability in the herbage (Fig. 1). Sedges were strongly and consistently selected for by bison in all seasons. Forbs were a significant herbage component (Table 2) but were strongly avoided by bison during all seasons (Fig. 1).

A diet composed primarily $(\mathbf{9 8 \%})$ of graminoids is consistent with studies on bison grazing preferences in other prairie types (Kautz and Van Dyne 1978, Schwartz and Ellis 1981, Plumb and Dodd 1993). The single largest dietary item was the bluestem complex, composed of the warm-season tallgrasses and little bluestem. Previous studies of bison grazing behavior on tallgrass prairie in Kansas have shown that bison preferentially graze many of these species after recent burning (Hartnett et al. 1996, Vinton et al. 1993). Pfeiffer and Hartnett (1995) found that fire removed standing dead tillers of little bluestem that were avoided by bison and thereby exposed more individual plants to defoliation. However, repeated defoliation of tallgrasses by bison also can be detrimental to the grasses by reducing growth rates and cover and altering plant population structure (Vinton and Hartnett 1992, Pfeiffer and Hartnett 1995).

Preferential grass herbivory by bison does incidentally benefit some prairie vegetation. Ungrazed forbs often are released from competition with nearby grazed grasses, which increases their growth and productivity (Fahnestock and Knapp 1994). The presence of bison grazing also results in a general increase in plant species diversity and spatial heterogeneity of vegetation due to bison-generated microsite diversity (Hartnett et al. 1996). Thus, the interaction between fire and bison grazing is an important influence on tallgrass prairie floristics because it alters both vegetative structure and diversity (Hartnett et al. 1996).

Consistent with studies conducted in other locations (Plumb and Dodd 1993, Van Vuren 1984, Peden et al. 1974), bison appear to avoid forbs in tallgrass prairie. Because forbs are generally more digestible than grasses, many studies recommend that correction factors be used with microhistological analysis to correct errors due to differential digestibility (Holechek et al. 1982). Other authors, noting that phenological variation in digestibility is often more significant than taxonomic variation, dismiss the use of corrective measures (Hansen et al. 1976). Because ours was a baseline study of seasonal food habits, we did not determine nor use correction factors. Thus, forb contribution to bison diets may be slightly underestimated in our study. Despite this, a diet trend remains evident - bison preferentially graze graminoids and avoid forbs in tallgrass prairie.

Bison showed some selectivity for grasses or consumed them in proportion to availability, but exhibited a consistent preference for sedges. Sedges are a major diet component for bison in northern areas of their range such as Yellowstone National Park (Meagher 1973), Canada (Reynolds et al. 1978, Larter and Gates 1991), and Alaska (Campbell and Hinkes 1983). Sedges are also more digestible than grasses in some locations (Hawley et al. 1981). However, a recent comprehensive study of mixed-grass prairie forages found only minor differences in digestibility between sedges (Carex sp.) and grasses in general (Plumb and Dodd 1993). Thus we do not believe the high composition of sedges in our study is the result of error during microhistological analysis. Instead, we believe bison may be using sedges because they are the most nutritious forage option available to them during winter, spring, and fall in southern tallgrass prairie. The study area is dominated by warm-season tallgrasses that have major vegetative growth during the late spring and summer portions of the growing season (Gillen and McNew 1987, Howe 1994). Tallgrasses are most nutritious during spring and early summer, but become coarse and rank during the remainder of the year (Waller et al. 1972). Sedges are cool-season graminoids with primary growth during cooler, wetter periods of the year (Howe 1994), a pattern supported by our herbage availability estimates (Table 2). Bison use of sedges, therefore, may be linked to a simple preference for green succulent forage during periods when warm-season grasses are either dormant or unpalatable. This would be especially important for lactating cows during late win-

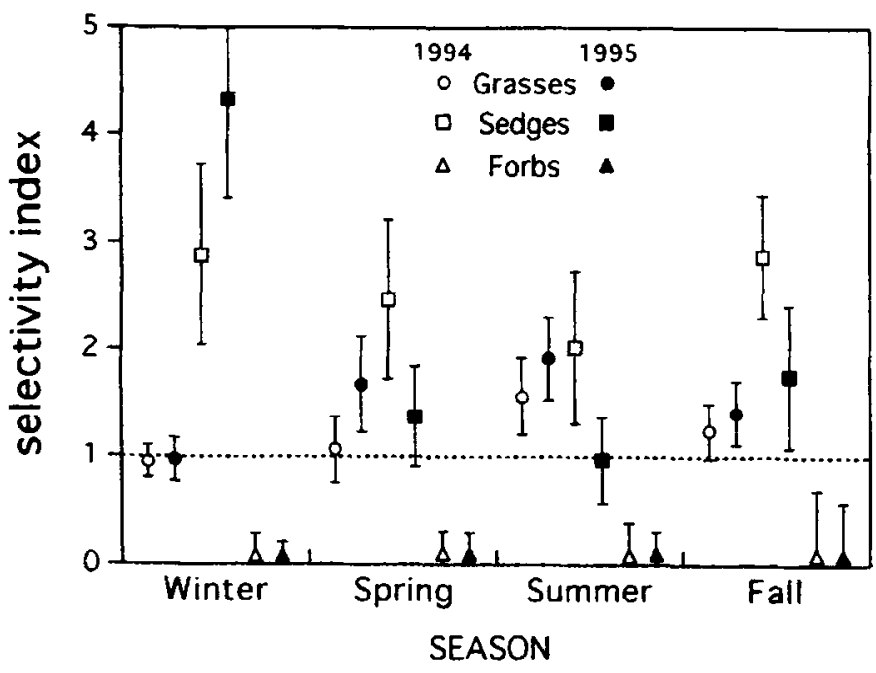

Fig. 1. Mean selectivity index values and $95 \%$ confidence intervals for seasonal bison diets on tallgrass prairie in Oklahoma, 1994-1995. Means with intervals that do not overlap 1.0 indicate selection $(>1.0)$ or avoidance $(<1.0)$ of the respective forage class (Hobbs and Bowden 1982). 
ter and early spring (March-April), when bison calves are usually born in Oklahoma (Halloran 1968). In our study, calving and associated nutritional demands corresponded to a time when sedge availability was highest (spring), which was when the major seasonal shifts in diet composition occurred. We suggest that future studies should consider evaluating the seasonal nutritional properties of sedges relative to grasses in studies of herbivore ecology on tallgrass prairie.

\section{Literature Cited}

Axelrod, D.I. 1985. Rise of the grassland biome, central North America Bot. Rev. 51:163-202.

Bourlier, B.G., J.D. Nichols, W.J. Ringwald, P.J. Workman, and S. Clemmons. 1979. Soil survey of Osage County, Oklahoma. USDASCS.

Campbell, B.H. and M. Hinkes. 1983. Winter diets and habitat use of Alaska bison after wildfire. Wildl. Soc. Bull. 11:16-21.

Collins, S.L. and L.L. Wallace. 1990. Fire in North American tallgrass prairies. Univ. Oklahoma Press, Norman, Okla.

Coppedge, B.R. 1996. Range ecology of bison on tallgrass prairie in Oklahoma. Ph.D. Thesis, Okla. State Univ., Stillwater, Okla.

Fahnestock, J.T. and A.K. Knapp. 1994. Plant responses to selective grazing by bison: interactions between light, herbivory, and water stress. Vegetatio 115:123-131.

Garretson, M.S. 1938. The American bison: the story of its extermination as a wild species and its restoration under federal protection. New York Zoological Society, New York.

Gillen, R.L. and R.W. McNew. 1987. Seasonal growth rates of tallgrass prairie after clipping. J. Range Manage. 40:342-345.

Gillen, R.L. and E.L. Smith. 1986. Evaluation of the dry-weight-rank method for determining species composition in tallgrass prairie. J. Range Manage. 39:283-285.

Halloran, A.F. 1968. Bison (Bovidae) productivity on the Wichita Mountains Wildlife Refuge, Okla. Southwest. Natur. 13:23-26.

Hartnett, D.C., K.R. Hickman, and I.E.F. Walter. 1996. Effects of bison grazing, fire, and topography on floristic diversity in tallgrass prairie. J. Range Manage. 49:413-420.

Hansen, R.M., T.M. Foppe, M.B. Gilbert, R.C. Clark, and H.W. Reynolds. 1976. The microhistological analysis of feces as an estimator of herbivore dietary. Unpublished report, AAFAB Composition Analysis Laboratory, Inc., Ft. Collins, Colo.

Hawley, A.W.L., D.G. Peden, H.W. Reynolds, and W.R. Stricklin. 1981. Bison and cattle digestion of forages from the Slave River Lowlands, Northwest Territories, Canada. J. Range Manage. 34:126-130.

Hobbs, N.T. and D.C. Bowden. 1982. Confidence intervals on food preference indices. J. Wildl. Manage. 46:505-507.

Holechek, J.L., M. Vavra, and R.D. Pieper. 1982. Botanical composition determination of range herbivore diets: a review. J. Range Manage. 35:309-315.

Howe, H.F. 1994. Response of early- and late-flowering plants to fire season in experimental prairies. Ecol. Appl. 4:121-133.

Joern, A. and K. Keeler. 1994. The changing prairie: North American grasslands. Oxford University Press, New York.

Kautz, J.E. and G.M. Van Dyne. 1978. Comparative analyses of diet of bison, cattle, sheep, and pronghorn antelope on shortgrass prairie in northeastern Colorado. Proc. First Internat. Range. Conf. 1:438-442.

Larter, N.C. and C.C. Gates. 1991. Diet and habitat selection of wood bison in relation to seasonal changes in forage quantity and quality. Can. J. Zool. 69:2677-2685.

Lechowicz, M.J. 1982. The sampling characteritics of electivity indices. Oecologia 52:22-30.

Loehle, C. and L.R. Rittenhouse. 1982. An analysis of forage preference indices. J. Range Manage. 35:316-319.

Main, M.B. and B.E. Coblentz. 1990. Sexual segregation among ungulates: a critique. Wildl. Soc. Bull. 18:204-210.
Meagher, M.M. 1973. The bison of Yellowstone National Park. Nati. Park Serv. Sci. Monogr. Ser. No. 1, 161 p.

McHugh, T. 1958. Social behavior of the American buffalo (Bison bison bison). Zoologica 43:1-54.

Peden, D.G. 1976. Botanical composition of bison diets on shortgrass plains. Amer. Midland Natur. 96:225-229.

Peden, D.G., G.M. Van Dyne, R.W. Rice, and R.M. Hansen. 1974. The trophic ecology of Bison bison L. on shortgrass plains. J. Appl. Ecol. 11:489-497.

Pfeiffer, K.E. and D.C. Hartnett. 1995. Bison selectivity and grazing response of little bluestem in tallgrass prairie. J. Range Manage. 48:26-31.

Plumb, G.E. and J.L. Dodd. 1993. Foraging ecology of bison and cattle on a mixed prairie: implications for natural area management. Ecol. Appl. 3:631-643.

Reynolds, H.W., R.M. Hansen, and D.G. Peden. 1978. Diets of the Slave River Lowland bison herd, Northwest Territories, Canada. J. Wildl. Manage. 42:581-590.

Risser, P.G., E.C. Birney, H.D. Blocker, S.W. May, W.J. Parton, and J.A. Wiens. 1981. The true prairie ecosystem. Hutchinson Ross, Stroudsburg, Penn.

Schwartz, C.C. and J.E. Ellis. 1981. Feeding ecology and niche separation in some native and domestic ungulates on the shortgrass prairie. J. Appl. Ecol. 18:343-353.

Shaw, J.H. 1995. How many bison originally populated western rangelands? Rangelands 17:148-150.

Sparks, D.R. and J.C. Malechek. 1968. Estimating percentage dry wcight in diets using a microscopic technique. J. Range Manage. 21:264-265.

Van Vuren, D. 1984. Summer diets of bison and cattle in southern Utah. J. Range. Manage. 37:260-261.

Vinton, M.A., and D.C. Hartnett. 1992. Effects of bison grazing on Andropogon gerardii and Panicum virgatum in burned and unburned tallgrass prairie. Oecologia 90:374-382.

Vinton, M.A., D.C. Hartnett, E.J. Finck, and J.M. Briggs. 1993. Interactive effects of fire, bison (Bison, bison) grazing and plant community composition in tallgrass prairie. Amer. Midland Natur. 129:10-18.

Waller, G.R., R.D. Morrison, and A.B. Nelson. 1972. Chemical composition of native grasses in central Oklahoma from 1947 to 1962 , Okla. St. Univ. Agr. Exp. Sta. Bull. B-697, Stillwater, Okla.

Wydeven, A.P. and R.B. Dahlgren. 1985. Ungulate habitat relationships in Wind Cave National Park. J. Wildl. Manage. 49:805-813. 